\title{
Detection of human immunodeficiency virus (HIV) RNA in the sweat of HIV-infected patients
}

\author{
(D) Fatih Mehmet Hanege, ${ }^{1}$ (1) Fatma Sargin, ${ }^{2}$ (1) Servet Karaca, ${ }^{1}$ (i) Oguz Kadir Egilmez, ${ }^{1}$ \\ (D) Haluk Vahaboglu, ${ }^{2}$ (D) M. Tayyar Kalcioglu ${ }^{1}$ \\ ${ }^{1}$ Department of Otorhinolaryngology, Istanbul Medeniyet University, Istanbul, Turkey \\ ${ }^{2}$ Department of Infectious Diseases and Clinical Microbiology, Istanbul Medeniyet University, Istanbul, Turkey
}

\begin{abstract}
OBJECTIVE: Human immunodeficiency virus (HIV) infection is a significant health problem. Many studies reported that HIV was mainly transmitted through parenteral exposure, sexual activity, and body secretions, such as saliva and semen. Many people, including health-care providers and patient relatives, may easily contact with the sweat of HIV-infected patients. Although reference books assert that HIV does not transmit through sweat, to our knowledge, there is no systemic study which this statement is based upon. This study aims to investigate the potential of sweat to transmit HIV infection.

METHODS: This study included 31 treatment-naive HIV RNA-positive patients who were in the acute phase of the infection and 26 subjects with a negative HIV RNA test who had received antiviral treatment. A total of 57 sweat samples collected from intact skin areas were prospectively evaluated by polymerase chain reaction (PCR) for the presence of HIV RNA. HIV RNA levels in the blood samples were also noted.
\end{abstract}

RESULTS: HIV RNA was not detected by PCR in any sweat sample taken from HIV-infected HIV RNA-negative and -positive subjects.

CONCLUSION: The findings obtained in this study suggest that sweat by itself has no potential for transmitting HIV infection.

Keywords: HIV; HIV transmission route; polymerase chain reaction; sweat.

Cite this article as: Hanege FM, Sargin F, Karaca S, Egilmez OK, Vahaboglu H, Kalcioglu MT. Detection of human immunodeficiency virus (HIV) RNA in the sweat of HIV-infected patients. North Clin Istanb 2020;7(1):6-10.

$\mathrm{H}_{\mathrm{i} \text { s }}$ (⿻上丨) uman immunodeficiency virus (HIV) infection is a worldwide health problem [1]. Although the worldwide incidence of HIV infection has decreased, the prevalence of HIV infection has increased with the increased life expectancy among patients receiving antiviral treatment (ART) [2].

Many studies reported that HIV was mainly transmitted through parenteral exposure, sexual activity, and body secretions, such as saliva and semen [1-3] A high HIV RNA level in blood is the greatest risk factor for the transmission of HIV [4] Risk of transmission can be reduced through early diagnosis, protection and decreasing HIV RNA levels by early treatment [5].

HIV-positive individuals get in contact with others in their daily lives. Health providers are in daily contact with patients, their blood and fluids. Some of the patients may be infected, or their fluids may be contaminated with HIV. Otorhinolaryngologists often get in contact with the face and scalp of patients during the physical examination, which gives rise to doubts about HIV transmission through exposure to sweat. Although reference books state that $\mathrm{HIV}$ is not transmitted via

Received: October 23, 2019 Accepted: May 23, 2019 Online: July 12, 2019

Correspondence: Dr. Fatih Mehmet HANEGE. Istanbul Medeniyet Universitesi Tip Fakultesi, Kulak Burun Bogaz Anabilim Dali, Istanbul, Turkey.

Tel: +905325026239 e-mail: hanege@hotmail.com

(c) Copyright 2020 by Istanbul Provincial Directorate of Health - Available online at www.northclinist.com 
sweat, to our knowledge, there is no systematic study on which this statement is based. In this study, we aimed to investigate the potential of contact with the sweat of HIV-positive patients to cause HIV infection.

\section{MATERIALS AND METHODS}

This study was approved by the local ethics committee. The patients were divided into two groups. Group 1 consisted of 31 treatment-naive HIV RNA-positive patients who were in the acute phase of the infection and Group 2 included 26 subjects with a negative HIV RNA test who had received antiviral treatment. The participants were asked to walk until they sweat. Sweat samples were collected from the face by an otorhinolaryngologist and put in sterile Eppendorf tubes. $0.5 \mathrm{cc}$ sterile saline was added to the tubes and the samples were placed in a deep freeze $\left(-32^{\circ} \mathrm{C}\right)$. After the collection of all the samples, the presence of HIV RNA was evaluated using the PCR method.

HIV RNA extraction followed by amplification and detection was performed according to the methodology mentioned elsewhere [6]. Briefly, RNA was extracted using

\section{TABLE 1. Sweat HIV RNA concentrations and serological parameters in group 1}

\begin{tabular}{|c|c|c|c|c|c|c|}
\hline Patient no. & Gender & Age & ART & $\mathrm{CD} 4$ & Serum HIV RNA (IU) & Sweat HIV RNA \\
\hline 1 & $M$ & 26 & Naive & 362 & 476973 & None detected \\
\hline 2 & M & 26 & Naive & 803 & 329 & None detected \\
\hline 3 & M & 59 & Naive & 8 & 775,774 & None detected \\
\hline 4 & M & 26 & Naive & 1046 & 114 & None detected \\
\hline 5 & M & 45 & Naive & 481 & 3290 & None detected \\
\hline 6 & $M$ & 26 & Naive & 675 & 19200 & None detected \\
\hline 7 & $\mathrm{~F}$ & 23 & Naive & 398 & 183303 & None detected \\
\hline 8 & M & 40 & Naive & 255 & 626246 & None detected \\
\hline 9 & M & 27 & Naive & 262 & 16410 & None detected \\
\hline 70 & M & 29 & Naive & 244 & 2187265 & None detected \\
\hline 11 & M & 21 & Naive & 287 & 482929 & None detected \\
\hline 12 & $M$ & 24 & Naive & 807 & 1068449 & None detected \\
\hline 13 & M & 37 & Naive & 906 & 102156 & None detected \\
\hline 14 & M & 32 & Naive & 410 & 87748 & None detected \\
\hline 15 & M & 31 & Naive & 254 & 14854 & None detected \\
\hline 16 & M & 30 & Naive & 301 & 322190 & None detected \\
\hline 17 & $M$ & 33 & Naive & 382 & 928394 & None detected \\
\hline 18 & $M$ & 22 & Naive & 170 & 610494 & None detected \\
\hline 19 & M & 42 & Naive & 209 & 583 & None detected \\
\hline 20 & M & 44 & Naive & 372 & 248,726 & None detected \\
\hline 21 & M & 36 & Naive & 312 & 5169 & None detected \\
\hline 22 & M & 34 & Naive & 230 & 435523 & None detected \\
\hline 23 & M & 26 & Naive & 397 & 5778788 & None detected \\
\hline 24 & M & 38 & Naive & 279 & 395533 & None detected \\
\hline 25 & M & 21 & Naive & 616 & 436 & None detected \\
\hline 26 & M & 28 & Naive & 237 & 49902 & None detected \\
\hline 27 & M & 24 & Naive & 413 & 52912 & None \\
\hline 28 & M & 30 & Naive & 320 & 437461 & None detected \\
\hline 29 & $M$ & 47 & Naive & 410 & 214 & None detected \\
\hline 30 & M & 29 & Naive & 646 & 303,856 & None detected \\
\hline 31 & M & 45 & Naive & 226 & 348,851 & None detected \\
\hline
\end{tabular}


TABLE2. Sweat HIV RNA concentrations, transmission routes, and serological parameters in group 2

\begin{tabular}{lcccccr} 
Patient no. & Gender & Age & ART & CD4 & Serum HIV RNA (IU) & Sweat HIV RNA \\
\hline 1 & M & 44 & + & 617 & Negative & None detected \\
2 & M & 34 & + & 313 & Negative & None detected \\
3 & M & 42 & + & 346 & Negative & None detected \\
4 & M & 49 & + & 173 & Negative & None detected \\
5 & M & 27 & + & 736 & Negative & None detected \\
6 & M & 34 & + & 966 & Negative & None detected \\
7 & M & 39 & + & 560 & Negative & None detected \\
8 & F & 40 & + & 988 & Negative & None detected \\
9 & M & 29 & + & 999 & Negative & None detected \\
10 & F & 33 & + & 424 & Negative & None detected \\
11 & M & 54 & + & 482 & Negative & None detected \\
12 & M & 35 & + & 691 & Negative & None detected \\
13 & M & 28 & + & 519 & Negative & None detected \\
14 & M & 31 & + & 822 & Negative & None detected \\
15 & M & 60 & + & 594 & Negative & None detected \\
16 & M & 51 & + & 527 & Negative & None detected \\
17 & M & 26 & + & 571 & Negative & None detected \\
18 & M & 33 & + & 680 & Negative & None detected \\
19 & M & 22 & + & 512 & Negative & None detected \\
20 & M & 32 & + & 542 & Negative & None detected \\
21 & M & 24 & + & 791 & Negative & None detected \\
22 & M & 25 & + & 708 & Negative & None detected \\
23 & M & 56 & + & 406 & Negative & None detected \\
24 & M & 28 & + & 1113 & Negative & None detected \\
25 & M & 37 & + & 350 & Negative & None detected \\
26 & M & 71 & + & 1223 & Negative & None detected \\
\hline & M & + & &
\end{tabular}

HIV: Human immunodeficiency virus; M: Male; F: Female; ART: Antiretroviral therapy.

the ready-to-use RNA extraction kit (QIAampUltraSens, QIAGEN, Hilden, Germany) according to the manufacturer's instructions. A 240 bp region of HIV RNA was reverse transcribed and amplified. Amplification and detection were performed in Rotor-Gene 2000/3000 (Corbett Research, Hamburg-Germany). Amplification protocol was as follows: one cycle of $50^{\circ} \mathrm{C}$ for $10 \mathrm{~min}, 45$ cycles of $95^{\circ} \mathrm{C}$ for $8 \mathrm{~s}, 55^{\circ} \mathrm{C}$ for $20 \mathrm{~s}$, and $72^{\circ} \mathrm{C}$ for $20 \mathrm{~s}$.

\section{RESULTS}

A total of 57 patients were included in this study. The study group consisted of three (5.2\%) female and 54 (94.7\%) male patients. The mean age of the patients was $34.8 \pm 10.9$ years (range: $21-71$ ). PCR assay showed no detectable HIV RNA in sweat samples of the two groups (Table 1,2). HIV RNA levels in serum and sweat samples are shown in Table 1 and 2 .

\section{DISCUSSION}

Studies showed that various body fluids, such as genital secretions, semen feces and saliva, may be HIV RNA positive in HIV-positive patients [4, 7-17]. In their study, Kantor et al. reported that HIV RNA was detected in genital secretions in 82 out of $143 \mathrm{HIV}$-positive patients [7]. Cotten et al. found HIV RNA in 12 out of 20 feces samples [9]. In their cross-sectional study, Liuzzi et al. detected HIV1 RNA in 25 semen samples out of 26 [10]. Balamane et al. reported measurable saliva HIV1 RNA in 36 of $47(77 \%)$ patients with plasma viremia [12]. Lourenco et al. [13] detected HIV RNA in 34 saliva 
TABLE 3. Studies on the prevalence of HIV RNA in different body fluids or secretions of HIV positive patients

\begin{tabular}{lccc} 
Study & $\begin{array}{c}\text { HIV positive } \\
\text { body fluid/secretion }\end{array}$ & Body fluid/secretion & $\begin{array}{c}\text { Positive HIV RNA } \\
\text { in body fluid/secretion } \\
\%\end{array}$ \\
\hline Kantor et al. 2014 [7] & 143 & Genital secretion & 57 \\
Cotten et al. 2014 [9] & 20 & Feces & 12 \\
Liuzzi et al. 1996 [10] & 26 & Semen & 25 \\
Balamane et al. 2010 [12] & 47 & Saliva & 36 \\
Lourenço et al. 2014 [13] & 57 & Saliva & 59 \\
Mohlala et al. 2005 [11] & 23 & Amniotic fluid & 0 \\
Mohlala et al. 2005 [11] & 23 & Fetal cord blood & 0 \\
Hanege et al. 2015 [6] & 78 & Cerumen & 0 \\
Current study & 57 & Sweat & 0 \\
\hline
\end{tabular}

HIV: Human immunodeficiency virus.

samples out of 57 and suggested that saliva may facilitate HIV entry and possibly other pathogens via the genital mucosa during heterosexual intercourse (Table 3). Detection of HIV RNA in samples collected, even from patients receiving the treatment demonstrates that the most efficient way to halt the disease progression is to know the ways of transmission and protection against transmission.

In addition to these studies showing the ways of transmission, there have been various studies reporting no HIV RNA in some body fluids. In a previous study, HIV RNA was not detected by PCR in-ear cerumen of patients with a positive test for serum HIV RNA [6]. Likewise, in a study, including 23 patients infected with HIV, Mohlala et al. [11] reported that no HIV RNA was found in amniotic fluids and umbilical cord blood of $23 \mathrm{HIV}$-infected pregnant women who received single-dose nevirapine or short-term zidovudine treatment before elective cesarean section (Table 3).

Although some statements are suggesting that HIV is not transmitted through sweat, in the literature, there are only a limited number of studies that we conducted on patients with a positive test for serum HIV RNA supporting those statements. Wormser et al. could not demonstrate HIV-RNA in eccrine sweat samples of 50 HIV-infected patients [18]. Reliable information and comment on this matter require more scientific research on patient samples. Thus, in this study, to base the subject upon a scientific foundation, we evaluated 31 treatmentnaive HIV RNA-positive patients who were in the acute phase of the infection and 26 subjects with a negative HIV RNA test who had received ART. All sweat samples analyzed using PCR were found to be negative for HIV RNA. This finding was a scientific result supporting the statements having no scientific basis in the literature.

\section{Conclusion}

The findings obtained in this study suggest that sweat from an HIV-infected individual that is not contaminated with blood or other body fluids has no potential for transmitting HIV infection even if serum HIV RNA level of the patient is considerably high. This result certainly does not ignore the necessity of precautions to prevent transmission of HIV during medical interventions or other approaches. General infection prevention should be precisely implemented.

Ethics Committee Approval: This study was approved by the Istanbul Medeniyet University, Goztepe Training and Research Hospital, Clinical Research Ethics Committee (Date: August 12, 2014; No: 2014/0121).

Conflict of Interest: No conflict of interest was declared by the authors.

Financial Disclosure: This work was supported by Istanbul Medeniyet University Research Fund (Grant number: T-BAG-2015-743).

Authorship Contributions: Concept - FMH, MTK, FS; Design FMH, HV, FS, MTK; Supervision - HV, MTK, FMH; Fundings - MTK, HV, FS, SK; Materials - OKE, SK, FMH, FS; Data collection and/or processing - FS, OKE, SK; Analysis and/or interpretation - FMH, MTK, FS, OKE, HV; Literature review - SK, OKE, MTK, HV; Writing FMH, MTK; Critical review - FMH, MTK, HV. 


\section{REFERENCES}

1. Maartens G, Celum C, Lewin SR. HIV infection: epidemiology, pathogenesis, treatment, and prevention. Lancet 2014;384:258-71. [CrossRef]

2. Zaidi J, Grapsa E, Tanser F, Newell ML, Bärnighausen T. Dramatic increase in HIV prevalence after scale-up of antiretroviral treatment. AIDS 2013;27:2301-5. [CrossRef]

3. Sooy CD, Gerberding JL, Kaplan MJ. The risk for otolaryngologists who treat patients with AIDS and AIDS virus infection: report of an in-process study. Laryngoscope 1987;97:430-4. [CrossRef]

4. Quinn TC, Wawer MJ, Sewankambo N, Serwadda D, Li C, WabwireMangen F, et al. Viral load and heterosexual transmission of human immunodeficiency virus type 1. Rakai Project Study Group. N Engl J Med 2000;342:921-9. [CrossRef]

5. Marks G, Crepaz N, Senterfitt JW, Janssen RS. Meta-analysis of highrisk sexual behavior in persons aware and unaware they are infected with HIV in the United States: implications for HIV prevention programs. J Acquir Immune Defic Syndr 2005;39:446-53. [CrossRef]

6. Hanege FM, Kalcioglu MT, Sargin F, Cetinkaya Z, Tekin M, Vahaboglu H. Does cerumen have a risk for transmission of HIV? Eur J Clin Microbiol Infect Dis 2015;34:789-93. [CrossRef]

7. Kantor R, Bettendorf D, Bosch RJ, Mann M, Katzenstein D, Cu-Uvin S, et al. HIV-1 RNA levels and antiretroviral drug resistance in blood and non-blood compartments from HIV-1-infected men and women enrolled in AIDS clinical trials group study A5077. PLoS One 2014;9:e93537.

8. Debiaggi M, Zara F, Spinillo A, De Santolo A, Maserati R, Bruno R, et al. Viral excretion in cervicovaginal secretions of HIV-1-infected women receiving antiretroviral therapy. Eur J Clin Microbiol Infect Dis 2001;20:91-6. [CrossRef]

9. Cotten M, Oude Munnink B, Canuti M, Deijs M, Watson SJ, Kellam P, et al. Full genome virus detection in fecal samples using sensitive nucleic acid preparation, deep sequencing, and a novel iterative sequence classification algorithm. PLoS One 2014;9:e93269. [CrossRef]

10. Liuzzi G, Chirianni A, Clementi M, Bagnarelli P, Valenza A, Cataldo PT, et al. Analysis of HIV-1 load in blood, semen and saliva: evidence for different viral compartments in a cross-sectional and longitudinal study. AIDS 1996;10:F51-6. [CrossRef]

11. Mohlala BK, Tucker TJ, Besser MJ, Williamson C, Yeats J, Smit L, et al. Investigation of HIV in amniotic fluid from HIV-infected pregnant women at full term. J Infect Dis 2005;192:488-91. [CrossRef]

12. Balamane M, Winters MA, Dalai SC, Freeman AH, Traves MW, Israelski DM, et al. Detection of HIV-1 in Saliva: Implications for CaseIdentification, Clinical Monitoring and Surveillance for Drug Resistance. Open Virol J 2010;4:88-93. [CrossRef]

13. Lourenço AG, Komesu MC, Machado AA, Bourlet T, Pozzetto B, Delézay $O$. Potential contribution of saliva to the sexual transmission of HIV through the secretion of CCL20 by genital epithelial cells. J Med Virol 2014;86:58-63. [CrossRef]

14. Robinson EK, Evans BG. Oral sex and HIV transmission. AIDS 1999;13:737-8. [CrossRef]

15. Page-Shafer K, Shiboski CH, Osmond DH, Dilley J, McFarland W, Shiboski SC, et al. Risk of HIV infection attributable to oral sex among men who have sex with menand in the population of men who have sex with men. AIDS 2002;16:2350-2. [CrossRef]

16. Spitzer PG, Weiner NJ. Transmission of HIV infection from a woman to a man by oral sex. N Engl J Med 1989;320:251. [CrossRef]

17. Han Y, Wu N, Zhu W, Li Y, Zuo L, Ye J, et al. Detection of HIV1 viruses in tears of patients even under long-term HAART. AIDS 2011;25:1925-7. [CrossRef]

18. Wormser GP, Bittker S, Forseter G, Hewlett IK, Argani I, Joshi B, et al. Absence of infectious human immunodeficiency virus type 1 in "natural" eccrine sweat. J Infect Dis 1992;165:155-8. [CrossRef] 